\title{
Relationship of post-weaning growth and age at puberty in crossbred beef heifers
}

\author{
Gabriel Ribas Pereira ${ }^{1}$, Júlio Otávio Jardim Barcellos ${ }^{1 *}$, Amir Gil Sessim¹, Jaime Urdapilleta \\ Tarouco², Fernanda Dornelles Feijó $^{2}$, José Braccini Neto², Ênio Rosa Prates², Maria Eugênia \\ Andrighetto Canozzi $i^{1}$
}

\footnotetext{
${ }^{1}$ Universidade Federal do Rio Grande do Sul, Departamento de Zootecnia, Núcleo de Estudos em Sistemas de Produção de Bovinos de Corte e Cadeia Produtiva, Porto Alegre, RS, Brazil.

2 Universidade Federal do Rio Grande do Sul, Faculdade de Agronomia, Departamento de Zootecnia, Porto Alegre, RS, Brazil.
}

\begin{abstract}
This study was intended to evaluate body size structure and growth parameters of crossbred heifers fed at four nutritional levels to achieve puberty earlier. Animals were classified depending on their level of crossing between Nelore and Hereford and subjected to four nutritional levels $\left(\mathrm{kg}\right.$ day $\left.{ }^{-1}\right)$ as follows: 0.5 (light; $\mathrm{n}=32$ ), 0.75 (medium; $\mathrm{n}=32$ ), 1.00 (high; $\mathrm{n}=29$ ), and 1.25 (very high; $\mathrm{n}=27$ ). Heifers at puberty and at weaning were individually classified for growth parameters. The fat thickness and longissimus muscle area throughout the experimental period were determined by ultrasonography. The height, heart girth, frame, and weight:height ratio were variables used to evaluate body traits. Univariate analysis of variance using the GLIM MIXED procedure os SPSS was performed and the significance level was set at 0.05 . Age and body weight at puberty were $388 \pm 1.9$ days and $331.4 \pm 1.3 \mathrm{~kg}$, respectively. Body condition score demonstrated an interaction between nutritional level and crossbred degree. Heifers with the highest degree of Nelore had higher fat thickness and lower weight:height ratio compared with other racial groups at puberty. Pearson correlation coefficient showed a negative association for body condition score $(-0.34)$ and fat thickness $(-0.58)$ compared with age at puberty. The increased fat thickness at younger ages at puberty was observed in all racial groups. The increased weight:height ratio at younger ages at puberty was observed in all racial groups. We observed higher values for a frame in animals at the higher level of supplementation. There is a greater correlation between live weight gain and phenotypic traits during weaning to achieve puberty at an earlier age in crossbred heifers.
\end{abstract}

Key Words: beef heifers, growth parameters, nutrition diets, productivity, ultrasonography

\section{Introduction}

Cow-calf production systems demand selection of beef heifers to reduce the requirements for animal replacement and to decrease long generation intervals (Aby et al., 2012; Santana et al., 2013). The average heifer weight at yearling suggests that the main limitation for breeding yearling is body weight at the start of the breeding season (Bolze and Corah, 1993; Perry, 2012). The age of first mating in beef cattle is an important event that has an economic impact on the production system efficiency (Hugh et al., 2011;

Received: August 17, 2016

Accepted: January 26, 2017

*Corresponding author: julio.barcellos@ufrgs.br

http://dx.doi.org/10.1590/S1806-92902017000500007

How to cite: Pereira, G. R.; Barcellos, J. O. J.; Sessim, A. G.; Tarouco, J. U.; Feijó, F. D.; Braccini Neto, J.; Prates, E. R. and Canozzi, M. E. A. 2017. Relationship of post-weaning growth and age at puberty in crossbred beef heifers. Revista Brasileira de Zootecnia 46(5):413-420.

Copyright (C) 2017 Sociedade Brasileira de Zootecnia. This is an Open Access article distributed under the terms of the Creative Commons Attribution License (http://creativecommons.org/licenses/by/4.0/), which permits unrestricted use, distribution, and reproduction in any medium, provided the original work is properly cited.
Laske et al., 2012). Thus, it is important to determine the balance between nutrient inflow in the post-weaning growth of crossbred beef heifers to achieve body weight conditons and earlier puberty to improve production efficiency.

Feeding supplementation is a management tool that can have the greatest impact on heifer development to achieve earlier puberty. Diets alter body composition in heifers, indicating that increase in nutrient intake would incrase body size and fatness at puberty (Hall et al., 1994; 1995). According to Cassady et al. (2009), the body weight or body fat plays an important role in the nutritional status appearance with a close relationship to the reproductive axis. Animals with larger body structure size can have a negative effect on reproductive performance, such as delay in age at puberty and reduced reproductive efficiency (Bouquet et al., 2010). Parameters such as live weight at the onset of puberty in heifers are important to establish adequate feeding systems from post-weaning period at the lowest possible production cost.

In addition to body weight at the beginning of the breeding season, post-weaning weight gain may also influence the pregnancy rate of heifers at 14 months 
(Eler et al., 2002; Santana et al., 2013). Overall, this study emphasizes the influences on supplementation intake strategies during growth of heifers at an earlier age and its effects on growth traits. The main objective of this study is to evaluate the relationship between post-weaning growth and age at puberty of crossbred beef heifers subjected to different nutritional diets. Therefore, we tested the hypothesis that puberty in crossbreed heifers is preceded by changes in body composition influenced by different diet supplementation.

\section{Material and Methods}

This study was conducted at a comercial farm located in Dom Pedrito, Rio Grande do Sul, Brazil (3055'28" S latitude and 54 $46^{\prime} 53^{\prime \prime} \mathrm{W}$ longitude and at $149 \mathrm{~m}$ altitude) and the climate of the region is considered subtropical, with rainfall evenly distributed throughout the year. The climate is classified as Cfa, according to the KöppenGeiger scale. The average annual rainfall is $1.300 \mathrm{~mm}$ and the average annual temperature is $18.6{ }^{\circ} \mathrm{C}$ (National Institute of Meteorology - INMET). The experimental trial began in May 2000 and ended in January 2001 when all heifers reached puberty.

All animals were grouped according to crossbred composition and were fed individually according to each treatment from weaning until the onset of puberty. Beef heifers were classified according to their Nelore $(\mathrm{N}) \times$ Hereford $(\mathrm{H}): 25 \% \mathrm{~N}-75 \% \mathrm{H}(25 \% \mathrm{~N}), 37.5 \% \mathrm{~N}-63.5 \% \mathrm{H}$ $(37.5 \% \mathrm{~N}), 43.7 \% \mathrm{~N}-56.7 \% \mathrm{H}(43.7 \% \mathrm{~N}), 50 \% \mathrm{~N}-50 \% \mathrm{H}(50 \% \mathrm{~N})$, and $75 \% \mathrm{~N}-25 \% \mathrm{H}(75 \% \mathrm{~N})$. The date and weight at birth, at weaning, and at one year of age were individually reported for all animals. Diets were designed to achieve a live body weight from 60 to $65 \%$ mature body weight at puberty for Braford breed (Patterson et al., 1992; NRC, 2000).

Composition of the supplement used to produce four rates of weight gain $\left(\mathrm{kg}\right.$ day $\left.^{-1}\right)$ were as follows: G500 $(\mathrm{n}=32)$ composed of 4.5 (dry matter $(\mathrm{DM}) \mathrm{kg}$ animal $^{-1}$ day $\left.^{-1}\right)$ of alfafa hay, $0.5\left(\mathrm{DM} \mathrm{kg}\right.$ animal ${ }^{-1}$ day $\left.^{-1}\right)$ of ground corn, and 2.27 metabolized energy (Mcal kg ${ }^{-1} \mathrm{DM}$ ); G750 $(\mathrm{n}=32)$ composed of $4.1\left(\mathrm{DM} \mathrm{kg}\right.$ animal ${ }^{-1}$ day $\left.^{-1}\right)$ of alfafa hay, 1.15 (DM kg animal ${ }^{-1}$ day $^{-1}$ ) of ground corn, and 2.39 metabolized energy (Mcal kg-1 DM); G1000 ( $n=29)$ composed of $3.0\left(\mathrm{DM} \mathrm{kg} \mathrm{animal}^{-1}\right.$ day $\left.^{-1}\right)$ of alfafa hay, 2.1 $\left(\mathrm{DM} \mathrm{kg}\right.$ animal ${ }^{-1}$ day $^{-1}$ ) of ground corn, 0.2 (DM kg animal ${ }^{-1}$ day $^{-1}$ ) of soybean meal, and 2.59 metabolized energy (Mcal kg $\left.{ }^{-1} \mathrm{DM}\right)$; and $\mathrm{G} 1250(\mathrm{n}=27)$ composed of $1.8(\mathrm{DM}$ $\mathrm{kg}$ animal ${ }^{-1}$ day $^{-1}$ ) of alfafa hay, $2.7\left(\mathrm{DM} \mathrm{kg} \mathrm{animal}^{-1}\right.$ day $\left.^{-1}\right)$ of ground corn, 0.8 (DM kg animal ${ }^{-1}$ day $^{-1}$ ) of soybean meal, and 2.82 metabolized energy (Mcal kg $\left.{ }^{-1} \mathrm{DM}\right)$. The expected four rates of weight gain were: $0.50 \mathrm{~kg}^{-1 a y^{-1}}$ (G500), $0.75 \mathrm{~kg}$ day $^{-1}$ (G750), $1.0 \mathrm{~kg} \mathrm{day}^{-1}$ (G1000), and $1.25 \mathrm{~kg} \mathrm{day}^{-1}$ (G1250) from weaning to puberty according to Barcellos et al. (2014).

All animals were kept outdoors in the same environmental conditions and had access to water ad libitum. Hay was offered $10 \%$ more than necessary in the diet with free access for all calves simultaneously in each paddlock location. To assess puberty, heifers at 8-9 months of age were exposed to an adult male with penile deviation to identify the presence of estrus behaviour. In addition, all heifers were subjected to estrus observation twice daily by visual assessment and follicular activity was evaluated by ultrassonography. Heifers showing estrus were evaluated by ultrasound using an Aloka Model SD-500 with $5 \mathrm{MHz}$ linear probe to identify the presence of the corpus luteum to confirm the begining of luteal activity.

The body weight at weaning (WW) was obtained every 28 days until the first estrus appearance to obtain the final body weight at puberty (WP). The average daily gain (ADG) from weaning to puberty $\left(\mathrm{kg} \mathrm{day}^{-1}\right)$ was obtained by the difference between the WW and WP, divided by the period between weaning and the onset of puberty. All heifers were also evaluated every 28 days to determine their body condition score (BCS). For all visual BCS evaluations, animals of the same management group were observed by a trained professional that used a scale of visual scores ranging from 1 to 5 (Lowman et al., 1976).

All heifers at the beginning of the experiment, at weaning, and at the time of puberty were measured using a proper ruler to determine the frame score (F) and the hip height $(\mathrm{H})$. Height measurenment was performed at the hip directly over the hook bones using a scale pole that was held vertically alongside the hip of the animal. Frame score was adjusted considering the height and age (days) of each animal, according to the methodology proposed by McPeake (1998). Thus, we considered frame as a description of the skeletal size in cattle applying the following formula: $\mathrm{F}=0.4723 \mathrm{H}-0.0239 \mathrm{D}+0.0000146 \mathrm{D}^{2}+0.000759 \mathrm{HD}$ -11.7086 ,

in which $\mathrm{F}$ is the frame, $\mathrm{H}$ is the height, and $\mathrm{D}$ is days at puberty.

All heifers were measured at the beginning of the experiment until puberty. Heart girth (HG) was measured as the minimal circumference around the body immediately behind the front shoulder for two consecutive times on each animal. Longissimus muscle area (LMA; $\mathrm{cm}^{2}$ ) and subcutaneous fat thickness (FAT; mm) ultrasounds were measured between the 12th and the 13th ribs. The ultrasound FAT was at $3 / 4$ of the lateral distance across 
the longissimus muscle between the 12th and13th ribs. Vegetable oil was used as an acoustic coupling in the ultrasound images and an acoustic rule (standoff) was used to facilitate contact between the transducer and the back of the animal. The ultrasound images were obtained using an ALOKA SSD-500 unit (Corometrics Medical Systems, Wallingford, CT) with a $3.5 \mathrm{MHz}$ linear probe model UST5044. These measurements were performed in all heifers at each weighing days, at ages 10, 11, and 12 months and at the day of puberty. The average ultrasound measurement obtained from duplicate images was used for statistical analyses. The variable weight:height ratio, in $\mathrm{kg} \mathrm{cm}^{-1}$, was included to provide a better assessment of the skeletal balance of each heifer.

A completely randomized design with a $4 \times 5$ factorial arrangement was used in this study. Firstly, data were subjected to linear regression to construct a model using the main factors that affect age at puberty in heifers. The initial model was:

$\mathrm{AP}($ age at puberty $)=\mu($ mean $)+\mathrm{WW}+\mathrm{ADG}+\mathrm{BCS}+$ $\% \mathrm{~N}(\%$ Nelore degree) $+\mathrm{WP}+\mathrm{W} 11$ (weight at 11 months) $+\mathrm{H}+\mathrm{HG}+\mathrm{F}+\mathrm{FAT}+\mathrm{FAT} 11$ (fat thickness at 11 months) + W:H11 (weight:height ratio at 11 months) + W:HP (weight: height ratio at puberty) + LMA.

The Tukey test was used to compare the effects of nutritional level and the interaction between nutrition and genetic group at weaning and age at puberty. The significance level was set at 0.05 . The univariate analysis of variance using the GLIM MIXED procedure of SPSS (Statistical Package for the Social Sciences, 1999) was performed by the method of least squares for unbalanced data using the final mathematical model:

$$
\mathrm{Y}_{\mathrm{ijk}}=\mu+\pi_{\mathrm{i}}+\omega_{\mathrm{j}}+(\pi \omega)_{\mathrm{ij}}+e_{\mathrm{ijk}},
$$

in which $\mathrm{Y}_{\mathrm{ijk}}$ is the observation of the individual $(\mathrm{k})$, at the nutritional level (i), and the $\% \mathrm{~N}$ degree $(\mathrm{j}) ; \mu$ is the overall mean; $\pi_{i}$ is the effect of nutritional level $i=1,2,3,4$; $\omega_{\mathrm{j}}$ is the effect of genetic group $\mathrm{j}=1,2,3,4,5 ;(\pi \omega)_{\mathrm{ij}}$ is the interaction between nutritional level $\mathrm{i}$ and genetic group $\mathrm{j}$; and $e_{\mathrm{ijk}}$ is the random error associated with each observation.

\section{Results}

Overall, calves were weaned in April, at 206 \pm 10 days of age and weighting $184.0 \pm 12 \mathrm{~kg}$. The final age and body weight at puberty were $388 \pm 1.9$ days and $331.4 \pm 1.3 \mathrm{~kg}$, respectively. After the linear regression analysis, changes in age at puberty were attributed to the effects of average daily gain from weaning to puberty, $\% \mathrm{~N}, \mathrm{FAT}, \mathrm{W}: \mathrm{H} 11$, and WP. The model that showed a better estimative (Table 1) of the age at puberty using the following equation is as follows:

$$
\begin{gathered}
\mathrm{AP}=437.96+(\% \mathrm{~N}) \times 0.46+\mathrm{WP} \times 0.71-\mathrm{W}: \mathrm{H} 11 \times 42.67 \\
-\mathrm{FAT} \times 9.95-\mathrm{ADG} \times 47.59-\mathrm{W} 11 \times 0.35
\end{gathered}
$$

The $\mathrm{W}: \mathrm{H}$ ratio at 11 months determined a delay by 4.2 days to puberty for each $0.1 \mathrm{~kg} \mathrm{~cm}^{-1}$ increased $(\mathrm{P}<0.01)$. In the final model, for every unit increased in FAT (mm), the puberty was reduced on average 9.9 days. We observed a delay by 4.7 days to puberty for each $0.1 \mathrm{~kg}^{\text {day }}{ }^{-1} \mathrm{ADG}$ increased $(\mathrm{P}<0.01)$.

Pearson correlation coefficient $(r>0.39)$ showed a negative association for BCS $(-0.37)$ and FAT $(-0.58)$ compared with age at puberty $(\mathrm{P}<0.01)$. However, we observed a positive association between BCS and FAT (0.39; $\mathrm{P}<0.01)$. The increased FAT at younger age at puberty was observed in all racial groups $\left(\mathrm{r}^{2}=0.54 ; \mathrm{P}<0.01\right)$ (Figure 1). The increased weight:height ratio at younger age at puberty was observed in all genetic groups $\left(\mathrm{r}^{2}=0.68 ; \mathrm{P}<0.01\right)$ (Figure 2).

The increased nutrient level after weaning determined higher FAT $(\mathrm{P}<0.01)$. In addition, heifers with the highest degree of Nelore had higher FAT $(\mathrm{P}<0.05)$ compared with other genetic groups at puberty. Heifers with the highest degree of Nelore at puberty affected the hip height at

Table 1 - Contribution of each variable in the final model adopted from weaning to puberty of beef heifers

\begin{tabular}{lccc}
\hline Variable & Increment & Unit & $\begin{array}{c}\text { Impact at age at } \\
\text { puberty (days) }\end{array}$ \\
\hline Crossbred heifers & 1.0 & $\%$ Nelore & 0.4 \\
Weight at puberty & 1.0 & $\mathrm{~kg}$ & 0.7 \\
Weight:height ratio at 11 months & 0.1 & $\mathrm{~kg} \mathrm{~cm}^{-1}$ & -4.2 \\
Back fat thickness at 11 months & 1.0 & $\mathrm{~mm}^{-1}$ & -9.9 \\
Average daily gain & 0.1 & $\mathrm{~kg} \mathrm{~d}^{-1}$ & -4.7 \\
Weight at 11 months & 1.0 & $\mathrm{~kg}$ & -0.3 \\
\hline
\end{tabular}

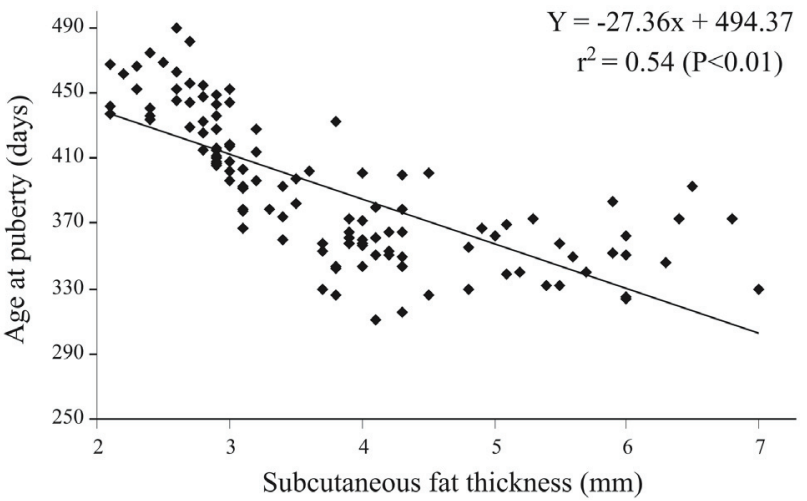

Figure 1 - Association of fat thickness (FAT) and age at puberty (AP) in crossbred beef heifers. 
puberty $(\mathrm{P}<0.01)$. Heifers with the highest degree of Nelore at puberty affected the frame score size $(\mathrm{P}<0.01)$. Groups receiving G1000 and G1250 showed higher values $(\mathrm{P}<0.01)$ for frame score compared with G500 nutritional group (Table 2).

\section{Discussion}

In the present experiment, the greater ADG produced higher body weight and lower age at puberty. The puberty weights obtained in this experiment are close to those reported by Samadi et al. (2014), in which the authors found values of approximately $357 \mathrm{~kg}$ in Brahman heifers. Rincker et al. (2011) subjected dairy heifers at an ADG of $0.95 \mathrm{~kg}$ during 180 days before the date predicted for puberty and observed puberty at 270 days. The accumulated weight gain at eleven months of age from the different genotypes had not been sufficient to show their development potential in body weight. Therefore, ADG allowed a more consistent analysis considering all heifers, regardless of the crossbred level. Martin et al. (1992) found a negative

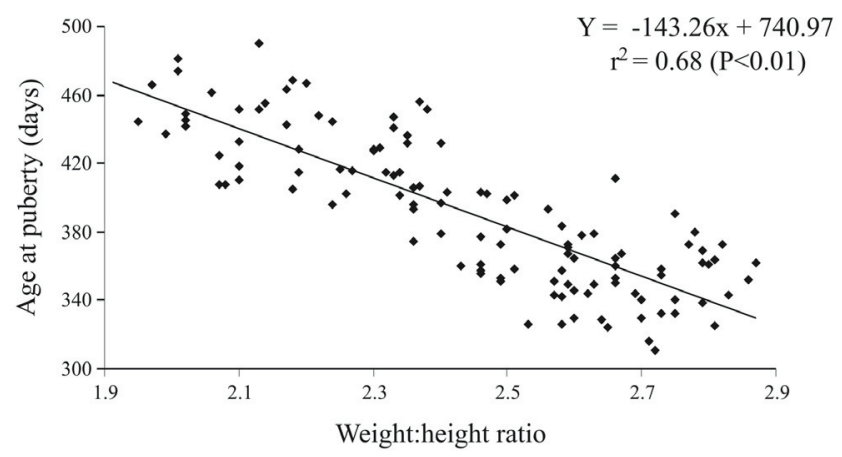

Figure 2 - Association of weight:height ratio (W:H) and age at puberty (AP) in crossbred beef heifers. genetic correlation between body weight at one year of age and at puberty. Thus, animals subjected to very low nutrient levels up to nine months and receiving a significant increase in the ADG may delay the puberty after that age. In addition, heifers supplemented by creep-feeding for 50 days altered physiological and metabolical variables to induce a faster body development to an earlier attainment of puberty (Guggeri et al., 2014; Reis et al., 2015). Indeed, strategies to earlier diet supplementation during this early sexual maturation period are an important determinant of puberty in heifers.

Recently, we have demonstrated an increase in follicular diameter in heifers fed high energy compared with animals fed low energy from 60 to 30 days prior to puberty (Barcellos et al., 2014). Summers et al. (2014) reported that conception rates increased in heifers with higher ADG based on corn level supplementation. In agreement, Larson et al. (2011) reported increased body weight after corn residue administration for winter grazing. Early post-weaning growth has a more profound effect on reproductive success in the first breeding season, indicating that weaning weight has a major impact on timing of puberty (Roberts et al., 2009) and can be consistently induced by a high-energy diet of beef heifers (Gasser et al., 2006). Banta et al. (2005) observed that two-year-old cows subjected to early weaning showed $92 \%$ of estrus appearance and $71 \%$ of conception rates, demonstrating that increasing energy intake of cows through early weaning should result in decreased postpartum interval and increased pregnancy rates. Thus, we observed that heifers with higher energy intake showed a larger body size that increased the demand for energy and protein; therefore, almost all heifers reached puberty by 15 months of age. Therefore, pre-weaning nutrition and ADG are strategies to improve the economic and biological efficiency of cow-calf production systems, allowing to anticipate the age of heifers at first breeding.

Table 2 - Phenotypic variations (mean \pm SEM) according to nutritional levels and \% Nelore at puberty in crossbred heifers

\begin{tabular}{|c|c|c|c|c|c|c|}
\hline & Animal (n) & UFAT (mm) & ULMA (mm) & Height $(\mathrm{cm})$ & Heart girth $(\mathrm{cm})$ & Frame \\
\hline \multicolumn{7}{|l|}{$\%$ Nelore } \\
\hline 25 & 16 & $4.7 \pm 0.3 \mathrm{a}$ & $51.7 \pm 1.6 \mathrm{a}$ & $124.0 \pm 1.1 \mathrm{a}$ & $161.5 \pm 1.3 \mathrm{a}$ & $6.3 \pm 0.3 \mathrm{a}$ \\
\hline 37.5 & 38 & $4.7 \pm 0.2 \mathrm{a}$ & $49.8 \pm 0.9 \mathrm{a}$ & $125.8 \pm 0.7 \mathrm{ab}$ & $160.0 \pm 1.0 \mathrm{a}$ & $6.0 \pm 0.2 \mathrm{a}$ \\
\hline 50 & 15 & $4.8 \pm 0.3 \mathrm{ab}$ & $47.6 \pm 1.2 \mathrm{a}$ & $128.2 \pm 1.5 b$ & $157.8 \pm 1.7 \mathrm{a}$ & $6.5 \pm 0.3 b$ \\
\hline 75 & 23 & $5.4 \pm 0.2 \mathrm{~b}$ & $52.8 \pm 1.1 \mathrm{a}$ & $133.3 \pm 0.7 \mathrm{c}$ & $160.7 \pm 1.3 \mathrm{a}$ & $7.3 \pm 0.2 \mathrm{c}$ \\
\hline \multicolumn{7}{|c|}{ Nutritional level $\left(\mathrm{kg}\right.$ day $\left.^{-1}\right)$} \\
\hline G750 & 32 & $4.3 \pm 0.2 \mathrm{a}$ & $47.7 \pm 0.9 \mathrm{a}$ & $126.4 \pm 0.8 \mathrm{a}$ & $158.2 \pm 0.9 \mathrm{a}$ & $6.1 \pm 0.2 \mathrm{ab}$ \\
\hline G1000 & 29 & $5.0 \pm 0.1 \mathrm{~b}$ & $50.2 \pm 1.2 \mathrm{ab}$ & $126.6 \pm 1.2 \mathrm{a}$ & $158.7 \pm 1.2 \mathrm{a}$ & $6.5 \pm 0.2 b c$ \\
\hline G1250 & 27 & $6.0 \pm 0.1 \mathrm{c}$ & $52.9 \pm 1.3 \mathrm{~b}$ & $127.3 \pm 1.0 \mathrm{a}$ & $159.1 \pm 1.3 \mathrm{a}$ & $6.7 \pm 0.2 \mathrm{c}$ \\
\hline
\end{tabular}

UFAT - ultrasound subcutaneous fat thickness; ULMA - ultrasound longissimus muscle area; SEM - standard error of the mean.

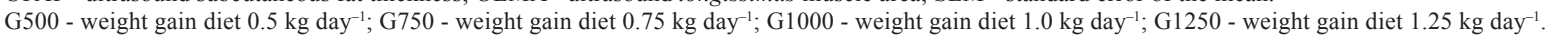

Values followed by different letters within a column differ significantly $(\mathrm{P}<0.05)$. 
The BCS is a subjective measure of visual assessment using different scales and evaluators. We observed that animals were supplemented within a period of at least 120 days of each experimental protocol and reached BCS at a specific period of supplementation to achieve puberty earlier in life. Hall et al. (1995) verified a BCS of 7.0 (scale from 1 to 9) at puberty in heifers with an increase rate of $1.0 \mathrm{~kg} \mathrm{day}^{-1}$. In the present study, we observed a correlation of -0.37 between the BCS and age of puberty indicating that the characteristics related to fat deposition influence puberty appearance. Walker et al. (2015) observed that heifers from heavier dams showed that a positive correlation existed between dam and heifer body weight that can affect selection goals for replacement heifers. Our data suggest a close agreement with other studies about beef breeds, in which visual appraisal were measured on live animals (Robinson et al., 1993; Queiroz et al., 2011).

Interestingly, for every unit increased in FAT, there was a reduction in 9.9 days to reach puberty in heifers. The effects of FAT reduction on age at puberty are smaller as heifer becomes fatter, suggesting that, from a minimum level of FAT, other factors begin to act in modulating the onset of puberty. This measurenment will provide valuable information to evaluate FAT at eleven months of age prior to puberty to indicate the need to target puberty earlier. The effects of FAT at specific age can alter the proportion of metabolically active tissues that influences the maintenance requirements (Buckley et al., 1990). Lammoglia et al. (2000) observed that feeding 4.4\% dietary fat increased the percentage of pubescent heifers by the beginning of the breeding season. Until the age of 12 months, there is a major change in the relationship between the proportions of structures of high energy demands with the rest of the body that could generate metabolic signals to trigger puberty. Nevertheless, studies on the effects of feeding supplemental fat at puberty in heifers are warranted.

On the other hand, younger animals subjected to supplementation of high energy levels have a greater deposition of fat than those subjected to lower-energy nutritional regiment (NRC, 2000); however, there is a genetic influence on fat deposition (Zuin et al., 2012). According to Martin et al. (1992), a lower lean:fat deposition ratio at puberty is observed in Bos indicus compared with British heifers. Studies using Santa Gertrudis and Angus heifers showed FAT deposition of 7.0 and $5.0 \mathrm{~mm}$, respectively, even though the age at puberty was similar between genetic groups (Hopper et al., 1993). Issues related to the experimental protocols, particularly with small differences in energy nutritional levels between treatments, produce major changes in FAT depositon that makes it difficult to identify correlations between FAT and age at puberty. Heifers with higher energy intake showed a larger body size that increased the demand for energy and protein (Bossis et al., 2000) and the mechanisms involved in this control are related to the activity of the GH receptors, since they act by stimulating the synthesis of IGF-I in the liver (Spicer et al., 2000).

We observed higher longissimus muscle area value of $52.9 \mathrm{~cm}^{2}$ of heifers kept in the G1250 nutritional group. The high correlation between longissimus muscle area and energy level after weaning is detected in Angus heifers (Hall et al., 1995). An important correlation between visual scores, live weights, and carcass traits obtained by ultrasound was found, which can be analyzed by univariate procedure (Pinto et al., 2013). Miar et al. (2014) indicated that ultrasound measurements of backfat thickness and ribeye area have strong genetic correlations with the corresponding measurements of carcass merit. Indeed, nutritional value is an important dimension of beef quality and this is reflected with the efforts to improve the fatty acid composition of beef.

We emphasized that higher Nelore crossbred heifers demonstrated higher hip height and frame score, which are phenotypic parameters commonly used to evaluate growth of heifers. The reproductive neuroendocrine postnatal system accelerates puberty during earlier calfhood, from 3 to 4.5 months of age, which might be facilitated by early programming of leptin secretion in adipose tissue during juvenile development using a stair-step nutritional regimen (Cardoso et al., 2014). Recently, Alves et al. (2015) described that the reduction in neuropeptide- $Y$ innervation of gonadotropin-releasing hormone neurons occurs in response to elevated body weight gain during the juvenile period. Nelore crossbred heifers had a higher heterozygosity, possibly due to a better adaptation to reach earlier puberty as described by Monteiro et al. (2013). Interestingly, it was also observed that heifers fed a high concentrate diet showed a continuously high rate of body weight gain after weaning (Cardoso et al., 2014). Thus, the evaluation of different crossbred phenotypic trends for body growth on a well-controlled nutritional regimen is important to achieve a significant improvement in growth efficiency of heifers.

Our data showed that heifers with higher degree of Nelore showed FAT, hip height, and frame score reaching puberty at a later stage. Crosses of British heifers with Nelore breed are expected to be higher due to the greater structure size of Nelore animals in relation to Hereford or Angus (Thallman et al., 1999). In addition, the nutritional level after weaning did affect the frame score size in heifers, as 
previously demonstrated by Yelich et al., (1996). In agreement, Hall et al. (1994) found no differences in height of heifers receiving $14 \mathrm{Mcal}_{\text {day }}{ }^{-1}$ or $10 \mathrm{Mcal} \mathrm{day}^{-1}$ of metabolisable energy. Indeed, the chest circumference showed no relationship with nutritional level and $\% \mathrm{~N}$ degree to reach puberty. The frame score is used to measure the size of the animal and represents a positive correlation with nutrient intake (Rocha et al., 2003). We observed higher frame score values as the percentage of Nelore degree increased. Higher energy intake may not have changed the curve of growth of long bones that grow in the same chronological speed from a given ADG (Lawrence and Fowler, 2002). According to Fox et al. (1988), animals with higher frame score require greater weight:height ratio to reach puberty than smaller animals. In addition, animals with large frame score size have delayed puberty under unfavorable environmental conditions (Euclides Filho et al., 2001). In our study, we analyzed frame score at G500 nutritional group and found an association with puberty. Indeed, we demonstrated that heifers with higher frame score reached puberty later when the rate of weight gain was limited. Similarly, Vargas et al. (1999), working with Brahman heifers in a tropical environment, found a high correlation between age at puberty at 672 and 626 days for animals with large and medium frame score, respectively.

We observed a tendency for heifers with higher $\% \mathrm{~N}$ degree to show a higher weight:height ratio in G1250 nutritional levels compared with other genetic groups. These data reflect higher body weight with a higher specific FAT, even though the body structure of these animals was higher at puberty. The relation weight:height is a good predictor of an animal body structure at weaning (Fox et al., 1988). Animals with greater size usually have an increase of the growth curve that results in the reduction of the onset of maturity and the accumulation of body fat, which may reflect a higher age at puberty (Perry and Cushman, 2013). In general, higher weight:height relationships at eleven months of age determine lower age at puberty, due to the fact that weight:height ratio results from other variables such as BCS, weight, and height. In our study, heifers with highest $75 \% \mathrm{~N}$ degree showed a higher FAT and frame score; however, these animals reached puberty later than other genetic groups. This is explained by the fact that Zebuin breed needs more time to reach puberty and to achieve body size conditions compared with British heifers.

\section{Conclusions}

The effects on supplementation intake strategies during heifer growth and body composition is an important approach to identify puberty at an earlier age. Animals subjected to a higher feeding level show higher subcutaneous fat thickness at puberty, indicating a greater correlation between body weight gain and phenotypic traits during weaning and puberty in crossbred heifers.

\section{Acknowledgments}

This study was supported by Coordenação de Aperfeiçoamento de Pessoal de Nível Superior (Project CAPES/PNPD no. 2842/2010) and Conselho Nacional de Desenvolvimento Científico e Tenológico (CNPq).

\section{References}

Aby, B. A.; Aass, L.; Sehested, E. and Vangen, O. 2012. Effects of changes in external production conditions on economic values of traits in Continental and British beef cattle breeds. Livestock Science 150:80-93. doi: 10.1016/j.livsci.2012.08.002.

Alves, B. R. C.; Cardoso, R. C.; Prezotto, L. D.; Thorson, J. F.; Bedenbaugh, M.; Sharpton, S. M.; Caraty, A.; Keisler, D. H.; Tedeschi, L. O.; Williams, G. L. and Amstalden, M. 2015. Elevated body weight gain during the juvenile period alters neuropeptide Y-gonadotropin-releasing hormone circuitry in prepubertal heifers. Biology of Reproduction 92:1-10. doi: 10.1095/biolreprod.114.124636.

Banta, J. P.; Lalman, D. L. and Wettemann, R. P. 2005. Post-calving nutrition and management programs for two-year-old beef cows. The Professional Animal Scientist 21:151-158. doi: 10.15232/ S1080-7446(15)31196-7.

Barcellos, J. O. J.; Pereira, G. R.; Dias, E. A.; McManus, C.; Canellas, L.; Bernardi, M. L.; Tarouco, A. and Prates, E. R. 2014. Higher feeding diets effects on age and live weight gain at puberty in crossbred Nelore $\times$ Hereford heifers. Tropical Animal Health Production 46:953-960. doi: 10.1007/s11250-014-0593-6.

Bolze, R. and Corah, L. R. 1993. Selection and development of replacement heifers. Kansas State University Cooperative. Extension Service, Manhattan. Available at: <http://www. bookstore.ksre.ksu.edu/pubs/C841.pdf $>$. Accessed on: Oct. 8, 2015.

Bossis, I.; Wettemann, R. P.; Welty, S. D.; Vizcarra, J. and Spicer, L. J. 2000. Nutritionally induced anovulation in beef Heifers: ovarian and endocrine function during realimentation and resumption of ovulation. Biology of Reproduction 62:1436-1444. doi: 10.1095/biolreprod62.5.1436.

Bouquet, A.; Fouilloux, M. N.; Renand, G. and Phocas, F. 2010. Genetic parameters for growth, muscularity, feed efficiency and carcass traits of young beef bulls. Livestock Science 129:38-48. doi: 10.1016/j.livsci.2009.12.010.

Buckley, B. A.; Baker, J. F.; Dickerson, G. E. and Jenkins T. G. 1990. Body composition and tissue distribution from birth to 14 months of beef heifers. Journal of Animal Science 68:3109-3123. doi: $10.2527 / 1990.68103109 x$.

Cardoso, R. C.; Alves, B. R. C.; Prezotto, L. D.; Thorson, J. F.; Tedeschi, L. O.; Keisler, D. H.; Park, C. S.; Amstalden, M. and Williams, G. L. 2014. Use of a stair-step compensatory gain nutritional regimen to program the onset of puberty in beef heifers. Journal of Animal Science 92:2942-2949. doi: 10.2527/jas.2014-7713.

Cassady, J. M.; Maddock, T. D.; Dicostanzo, A. and Lamb, G. C. 2009. Body composition and estrous cyclicity responses of heifers of distinct body conditions to energy restriction and repletion. Journal of Animal Science 87:2255-2261. doi: 10.2527/jas.2008-1715. 
Eler, J. P.; Silva, J. A. I. I. V.; Ferraz, J. B.; Dias, F.; Oliveira, H. N.; Evans, J. L. and Golden, B. L. 2002. Genetic evaluation of the probability of pregnancy at 14 months for Nellore heifers. Journal of Animal Science 80:951-954. doi:-10.2527/2002.804951x.

Euclides Filho, K.; Feijo, G. L. D.; Figueiredo, G. R.; Euclides, V. P. B.; Silva, L. O. C. and Cusinato, V. Q. 2001. Effect of age at castration and genetic groups on performance and carcass traits. Revista Brasileira de Zootecnia 30:71-76. doi: 10.1590/S151635982001000100012 .

Fox, D. G.; Sniffen, C. J. and O'Connor, J. D. 1988. Adjusting nutrient requirements of beef cattle for animal and environmental variations. Journal of Animal Science 66:1475-1453. doi: 10.2527/ jas 1988.6661475x.

Gasser, C. L.; Behlke, E. J.; Grum, D. E. and Day, M. L. 2006. Effect of timing of feeding a high-concentrate diet on growth and attainment of puberty in early-weaned heifers. Journal of Animal Science 84:3118-3122. doi: 10.2527/jas.2005-676.

Guggeri, D.; Meikle, A.; Carriquiry, M.; Montossi, F.; De Barbieri, I. and Viñoles, C. 2014. Effect of different management systems on growth, endocrine parameters and puberty in Hereford female calves grazing Campos grassland. Livestock Science 167:455-462. doi: 10.1016/j.livsci.2014.06.026.

Hall, J. B.; Schillo, K. K.; Fitzgerald, B. P. and Bradley, N. W. 1994. Effects of recombinant bovine somatotropin and dietary energy intake on growth, secretion of luteinizing hormone, follicular development, and onset of puberty in beef heifers. Journal of Animal Science 72:709-718. doi: 10.2527/1994.723709x.

Hall, J. B.; Staigmiller, R. B.; Bellows, R. A.; Short, R. E.; Moseley, W. M. and Bellows, S. E. 1995. Body composition and metabolic profiles associated with puberty in beef heifers. Journal of Animal Science 73:3409-3420. 2016. doi: 10.2527/1995.73113409x.

Hopper, H. W.; Williams, S. E.; Byerley, D. J.; Rollosson, M. M.; Ahmed, P. O. and Kiser, T. E. 1993. Effect of prepubertal body weight gain and breed on carcass composition at puberty in beef heifers. Journal of Animal Science 71:1104-1111. doi: 10.2527/ 1993.7151104x.

Hugh, N. M. C.; Evans, R. D.; Amer, P. R.; Fahey, A. G. and Berry, D. P. 2011. Genetic parameters for cattle price and body weight from routinely collected data at livestock auctions and commercial farms. Journal of Animal Science 89:29-39. doi: 10.2527/jas.2010-3044.

Lammoglia, M. A.; Bellows, R. A.; Grings, E. E.; Bergman, J. W.; Bellows, S. E.; Short, R. E.; Hallford, D. M. and Randel, R. D. 2000. Effects of dietary fat and sire breed on puberty, weight, and reproductive traits of F1 beef heifers. Journal of Animal Science 78:2244-2252. doi: 10.2527/2000.7892244x.

Larson, D. M.; Cupp, A. S. and Funston, R. N. 2011. Heifer development systems: A comparison of grazing winter range or corn residue. Journal of Animal Science 89:2365-2372. doi: 10.2527/jas.2010-3767.

Laske, C. H.; Teixeira, B. B. M.; Dionello, N. J. L. and Cardoso, F. F. 2012. Breeding objectives and economic values for traits of low input family-based beef cattle production system in the State of Rio Grande do Sul. Revista Brasileira de Zootecnia 41:298-305. doi: 10.1590/S1516-35982012000200010.

Lawrence, T. L. J. and Fowler, V. R. 2002. Growth of farm animals. 2nd ed. Cambridge University, CAB-International, London.

Lowman, B. G.; Scott, N. A. and Somerville, S. H. 1976. Condition scoring of cattle. Bulletin 6. East of Scotland College of Agriculture, Edinburgh, UK.

Martin, L. C.; Brinks, J. S.; Bourdon, R. M. and Cundiff, L. V. 1992. Genetic effects on beef heifer puberty and subsequent reproduction. Journal of Animal Science 70:4006-4017. doi: $10.2527 / 1992.70124006 x$.

McPeake, C. A. 1998. Hip height and frame score determination. Oklahoma Cooperative Extension Service, Publication No. 3271, Stillwater, USA.
Miar, Y.; Plastow, G. S.; Bruce, H. L.; Moore, S. S.; Durunna, O. N.; Nkrumah, J. D. and Wang, Z. 2014. Estimation of genetic and phenotypic parameters for ultrasound and carcass merit traits in crossbred beef cattle. Canadian Journal of Animal Science 94:273-280. doi: 10.4141/cjas2013-115.

Monteiro, F. M.; Mercadante, M. E. Z.; Barros, C. M.; Satrapa, R. A.; Silva, J. A. V.; Oliveira, L. Z.; Saraiva, N. Z.; Oliveira, C. S. and Garcia, J. M. 2013. Reproductive tract development and puberty in two lines of Nelore heifers selected for postweaning weight. Theriogenology 80:10-17. doi: 10.1016/j.theriogenology.2013.02.013.

NRC - National Research Council. 2000. Nutrient requirements of beef cattle. 7th rev. ed. Update 2000. National Academy Press, Washington, D.C., USA.

Patterson, D. J.; Perry, R. C.; Kiracofe, G. H.; Bellows, R. A.; Staigmiller, R. B. and Corah, L. R. 1992. Management considerations in heifer development and puberty. Journal of Animal Science 70:4018-4035. doi: 10.2527/1992.70124018x.

Perry, G. A. 2012. Physiology and Endocrinology Symposium: harnessing basic knowledge of factors controlling puberty to improve synchronization of estrus and fertility in heifer. Journal of Animal Science 90:1172-1182. doi: 10.2527/jas.2011-4572.

Perry, G. A. and Cushman, R. 2013. Effect of age at puberty/conception date on cow longevity. The veterinary clinics of North America: Food Animal Practice 29:579-590. doi: 10.1016/j.cvfa.2013.07.011.

Pinto, L. F. B.; Tarouco, J. U.; Pedrosa, V. B.; de Farias Jucá, A.; Leão, A. G. and Moita, A. K. 2013. Live weight, carcass ultrasound images, and visual scores in Angus cattle under feeding regimes in Brazil. Tropical Animal Health and Production 45:1281-1287. doi: 10.1007/s11250-013-0358-7.

Queiroz, S. A.; Oliveira, J. A.; Costa. G. Z. and Fries, L. A. 2011. Estimates of genetic parameters for visual scores and daily weight gain in Brangus animals. Animal 5:838-843. doi: 10.1017/ S1751731110002442.

Reis, M. M.; Cooke, R. F.; Cappellozza, B. I.; Marques, R. S.; Guarnieri Filho, T. A.; Rodrigues, M. C.; Bradley, J. S.; Mueller, C. J.; Keisler, D. H.; Johnson, S. E. and Bohnert, D. W. 2015. Creep-feeding to stimulate metabolic imprinting in nursing beef heifers: impacts on heifer growth, reproductive and physiological variables. Animal 9:1500-1508. doi: 10.1017/S1751731115000828.

Rincker, L. E. D.; Vandehaar, M. J.; Wolf, C. A.; Liesman, J. S.; Chapin, L. T. and Nielsen, M. S. W. 2011. Effect of intensified feeding of heifer calves on growth, pubertal age, calving age, milk yield, and economics. Journal of Dairy Science 94:3554-3567. doi: 10.3168/jds.2010-3923.

Roberts, A. J.; Geary, T. W.; Grings, E. E.; Waterman, R. C. and MacNeil, M. D. 2009. Reproductive performance of heifers offered ad libitum or restricted access to feed for a one hundred forty-day period after weaning. Journal of Animal Science 87:3043-3052. doi: 10.2527/jas.2008-1476.

Robinson, D. L.; Hammond, K. and MacDonald, C. A. 1993. Live animal measurement of carcass traits: estimation of genetic parameters for beef cattle. Journal of Animal Science 71:11281135. doi: 10.2527/1993.7151128x.

Rocha, E. D.; Andrade, V. J.; Euclides Filho, K.; Nogueira, E. and Figueiredo, G. R. 2003. Tamanho de vacas Nelore adultas e seus efeitos no sistema de produção de gado de corte. Arquivo Brasileiro de Medicina Veterinária e Zootecnia 55:474-479. doi: 10.1590/S0102-09352003000400014.

Samadi, F.; Blache, D.; Martin, B. G. and D’Occhio, M. J. 2014. Nutrition, metabolic profiles and puberty in Brahman (Bos indicus) beef heifers. Animal Reproduction Science 146:134-142. doi: 10.1016/j.anireprosci.2014.03.004.

Santana, M. L. Jr.; Eler, J. P.; Bignardi, A. B. and Ferraz, J. B. S. 2013. Genetic associations among average annual productivity, growth traits, and stayability: A parallel between Nelore and 
composite beef cattle. Journal of Animal Science 91:2566-2574. doi: $10.2527 /$ jas.2012-5856.

Spicer, L. J.; Alvares, P.; Prado, R. M.; Morgan, G. L. and Hamilton, T. D. 2000. Effects of intraovarian infusion of insulin-like growth factor-I on ovarian follicular function in cattle. Domestic Animal Endocrinology 18:265-278. doi: 10.1016/S0739-7240(99)00084-3.

Summers, A. F.; Weber, S. P.; Lardner, H. A. and Funston, R. N. 2014. Effect of beef heifer development system on average daily gain, reproduction, and adaptation to corn residue during first pregnancy. Journal of Animal Science 92:2620-2629. doi: 10.2527/jas.2013-7225.

Thallman, R. M.; Cundiff, L. V.; Gregory, K. E. and Koch, R. M. 1999. Germplasm evaluation in beef cattle-cycle IV: Postweaning growth e puberty of heifers. Journal of Animal Science 77:26512659. doi: $10.2527 / 1999.77102651 x$.

Vargas, C. A.; Olson, T. A.; Chase, C. C.; Hammond, A. C. and Elzo, M. A. 1999. Influence of frame size and body condition score on performance of Brahman cattle. Journal of Animal Science 77:3140-3139. doi: 10.2527/1999.77123140x.

Walker, R. S.; Martin, R. M. and Buttrey, B. 2015. Effects of residual feed intake and dam body weight on replacement heifer intake, efficiency, performance, and metabolic response. Journal of Animal Science 93:3602-3612. doi: 10.2527/jas.2015-9040.

Yelich, J. V.; Wettemann, R. P.; Marston, T. T. and Spicer, L. J. 1996. Luteinizing hormone, growth hormone, insulin-like growth factor I, insulin and metabolites before puberty in heifers fed to gain at two rates. Domestic Animal Endocrinology 13:325-338. doi: 10.1016/0739-7240(96)00046-X.

Zuin, R. G.; Buzanskas, M. E.; Caetano, S. L.; Venturini, G. C.; Guidolin, D. G. F.; Grossi, D. A.; Chud, T. C. S.; Paz, C. C. P.; Lôbo, R. B. and Munai, D. P. 2012. Genetic analysis on growth and carcass traits in Nelore cattle. Meat Science 91:352-35. doi: 10.1016/j.meatsci.2012.02.018. 